\title{
Hypopharyngeal Cancer Clinical Distant Metastasis TNM Finding v7
}

National Cancer Institute

\section{Source}

National Cancer Institute. Hypopharyngeal Cancer Clinical Distant Metastasis TNM

Finding V7. NCI Thesaurus. Code C89042.

A clinical finding about one or more characteristics of hypopharyng eal cancer, following the rules of the TNM AJCC v7 classification system as they pertain to distant metastases. 